\title{
Effects of Cultivar, Planting Period, and Fungicide Usage on Rice Blast Infection Levels and Crop Yield
}

\author{
Andi Nasruddin ${ }^{1} \&$ Nur Amin ${ }^{1}$ \\ ${ }^{1}$ Department of Plant Pests and Diseases, Hasanuddin University, South Sulawesi Indonesia \\ Correspondence: Andi Nasruddin, Department of Plant Pests and Diseases, Hasanuddin University, South \\ Sulawesi Indonesia. E-mail: andinasruddin@yahoo.com
}

Received: June 30, 2012 Accepted: August 13, 2012 Online Published: December 13, 2012

doi:10.5539/jas.v5n1p160

URL: http://dx.doi.org/10.5539/jas.v5n1p160

\begin{abstract}
Studies were separately conducted to determine the effects of cultivar, planting date, and fungicide usage on rice blast disease, caused by Pyricularia grisea (Cooke) Sacc. [= Magnaporthe grisea (Hebert) Barr] in Kecamatan Manggala, South Sulawesi Indonesia. The four rice varieties were IR-66, Cisantana, Cigeulis, and Filipin. The results showed that IR-66 was moderately resistant to leaf and neck blast, with the lowest percentage unfilled grains per panicle. Cisantana reacted moderately resistant to leaf blast, but moderately susceptible to neck blast. Cigeulis was moderately susceptible to leaf and neck blast, while Filipin showed a highly susceptible reaction to both leaf and neck blast, and a 31\% plant population death due to the blast disease. With respect to planting dates (February 4, March 22, and May 16), plants transplanted in March had the highest leaf blast severity, neck blast incidence, and the lowest yield. Seven fungicides (four are recommended for use in rice in Indonesia: flusilazol, difenoconazole, difenokonazole+propikonazole, and carbendazim $(6.2 \%)+$ mancozeb $(73.8 \%))$ and three generally used ones (menefoxam (4\%)+mancozeb (64\%), chlorothalonyl, and metalaxyl) which were evaluated against the rice blast disease, showed the recommended fungicides for use in rice to be more effective in suppressing blast and protecting yield, compared to the other fungicides.
\end{abstract}

Keywords: AUDPC, field trial, rice blast, Pyricularia grisea, susceptibility, resistance

\section{Introduction}

Rice blast, caused by the fungus Pyricularia grisea (Cooke) Sacc. [= Magnaporthe grisea (Hebert) Barr], is one of the most devastating diseases of rice (Oryza sativa L.) worldwide. In Indonesia, the disease has been reported causing severe damage to plant in many parts of the country. Significant losses of 1,781 ha, 1,084 ha, 624 ha, 395 ha, and 200 ha due to severe infection of blast were recorded in the Provinces of West Java, South Sumatera, North Sumatera, Central Kalimantan, and West Nusa Tenggara, respectively (Hasanuddin, 2004). There is a tendency that the disease has become increasingly important, reflected by the most recent data indicating that 10,604 ha and 11,929 ha of rice field throughout the country were damaged by blast in 2010 and 2011 , respectively (Wibowo, 2011).

Blast can infect most parts of the plant: leaf, collar, node, internode, neck, and other parts of panicle, but rarely infects leaf sheath (IRRI 2010). Blast infection can cause yield loss up to $80 \%$, depending on inoculum pressure, crop growth stage at infection, prevailing climatic conditions, varietal susceptibility, and cultural practices (Groth, 2006; Prabhu et al., 2006). Environments with frequent and prolonged dew periods and with cool temperatures in the day time are most favorable to blast, especially in upland and rain-fed environments in the tropics and subtropics (IRRI, 2010). Besides that, lack of flooding during planting season also predisposes plants to blast infection (Lee et al., 2003; Singh et al., 2004).

Rice cultivars have different reactions to blast disease, ranging from susceptible to resistant. However, very few rice cultivars available currently are resistant to the disease. Recently, the disease has been reported infecting newly released high-yielding cultivars. Some of these cultivars are mildly resistant to leaf blast but more susceptible to head blast (Tangdiabang \& Pakki, 2006).

Early planting date can help susceptible cultivars escape from severe infection of leaf blast but can be infected by head blast at the onset of panicles. However, if susceptible cultivars are planted later in the season, the plants 
can be severely infected by both leaf and head blight. When epidemic starts early, in late sown plantings, plant growth and development are severely affected, resulting in death of many plants (Filippi \& Prabu, 1997).

Fungicides have been used effectively to control blast but the effectiveness of particular fungicides could vary from place to place or season to season. Farmers are advised to rotate the fungicides used to prevent the fungus from developing resistance against those fungicides (Tangdiabang \& Pakki, 2006). Therefore, information about effective fungicides with different modes of action should be available to farmers.

In order to achieve an effective and sustainable control of the blast disease, a management strategy integrating the use of resistant cultivar, appropriate planting date, and fungicide must be developed. Therefore, the objectives of the current study were to determine: 1) the response of four rice cultivars to the leaf and neck blast severities and percent of unfilled grains; 2) the effects of three different planting periods on the leaf and neck blast severities and crop yield; and 3) the effects of seven fungicide formulations on the leaf and neck blast severities and crop yield.

\section{Materials and Methods}

\subsection{Blast Infection on Four Rice Varieties}

A field survey was conducted to assess leaf blast severity and neck blast incidence on four rice varieties: IR-66, Cisantana, Cigeulis, and Filipin. The varieties were chosen because they comprised of approximately $70 \%$ of rice plantation in the study site at the time of the survey. The study was conducted from April to September 2010 in farmers' fields in the District of Manggala, Makassar in the South Sulawesi Province of Indonesia. The study site was a rain-fed area about 400 ha of continuous rice plantation encompassing four subdistricts: Kassi, Kajenjeng, Romang Tangaya, and Rappocedu. In each subdistrict, four fields individually planted with each of the four cultivars, with about the same age of 30 to 35 days after transplanting (DAT), were selected for disease observation. Field sizes ranged from 0.25 to 0.5 ha. The subdistricts were considered as replications in this study. None of those farmers applied fungicides, but they applied insecticides to control other pests such as rice leafhoppers and stem borers.

To assess leaf blast severity (LBS), twenty rice hills in each field were randomly selected from central rows of the field. Six tillers per hill and four fully expanded leaves on each tiller were observed to assess leaf blast severity. Leaf blast was evaluated three times, on 30,37, and 44 DAT. Percentage of diseased leaf area was estimated visually (Bonman et al., 1991). The percentage values were then subjected to the formula below to assess the area under disease progress curve (AUDPC) (Shaner \& Finney, 1977):

$$
A U D P C=\sum_{i=1}^{n}\left[\frac{\left(y_{i}+y_{i+1}\right)}{2}\right]\left(t_{i+1}-t_{i}\right)
$$

Where, $y_{i}=$ percent of diseased leaf area on the $i$ th date, $t_{i}=$ date on which the disease was scored (ith day), $\mathrm{n}=$ number of dates on which disease was scored.

Varietal reactions to leaf blast was determined using standard evaluation system (SES) on 0 to 9 scales (where $0=$ no lesion development and $9=$ all leaves dead). A cultivar was classified as resistant (R) when the ranking was from 0 to 2 (i.e. no symptoms to non-sporulating spots), moderately resistant (MR) with ranking from 3 to 4 (small lesions surrounded by necrosis with little sporulation), moderately susceptible (MS) with ranking from 4 to 5 (typical spindle-shaped lesions, $3 \mathrm{~mm}$ or larger, sporulating heavily), and susceptible (S) with it ranked from 5 to 9 (more than 25\% leaf area covered by spores to dead leaf) (Chaudary, 2001).

Neck blast incidence (NBI) was scored seven days before harvest by randomly observing 200 panicles per variety in each location. Percent of neck blast was determined by counting the number of panicles showing severe neck blast symptoms (scores from 7 to 9) (IRRI, 2011) for each cultivar. Percent of panicles with neck blast was calculated using the formula below (Greer \& Webster, 2001):

$$
N B I=\frac{A}{B} \times 100 \%
$$

where, $A=$ the number of panicles with severe neck blast (scores from 7 to 9); $B=$ the number of panicles observed for each cultivar per location (200 panicles). Based on the neck blast incidence, cultivars or lines were classified as resistant (R) with $0-15 \%$; moderately resistant (MR) with $15.1-30 \%$; moderately susceptible (MS) with 30.1-50\%; or susceptible (S) with 50.1-100\% (Puri et al., 2009). 


\subsection{Planting Date Effect}

A field experiment was conducted to determine the effect of planting date on leaf blast severity and neck blast incidence. Rice var. Filipin, a susceptible cultivar was transplanted at three different dates: February 4, March 22, and May 16, 2011. No fungicide was applied on the experimental site. Fertilizers were applied in accordance with the local recommendations. Insecticides were applied as necessary, mainly to control leafhoppers and stem borers. Planting date treatments were arranged in a completely randomized design with seven replications. Each replication consisted of a plot with ten rows wide and $15 \mathrm{~m}$ long, and planting space of $25 \times 25 \mathrm{~cm}$. There was a bare space of $1.5 \mathrm{~m}$ between plots. The experimental plots were surrounded by farmers' fields with rice var. Filipin, which were heavily infected by blast. Leaf blast severity was scored on 30, 37, and 44 DAT for each planting date treatment. The percentages of diseased leaf area were visually estimated on 20 randomly selected hills per plot, which were then subjected to formula 1 for AUDPC assessment.

Neck blast severity was evaluated seven days before harvest by randomly observing 100 panicles per plot, while percentage neck blast evaluation was determined by counting the number of panicles showing neck blast symptoms with scoring 7 to 9 , among the 100 sample plants in each plot (Formula 2).

\subsection{Fungicide Effect}

A field experiment was conducted to determine the effect of fungicide applications on LBS, NBI, and rice yield. Seedlings Filipin were transplanted on May 1, 2011 and fertilizers were applied following local recommendations. Insecticides were also applied as necessary to control leafhoppers and stem borers. Treatments consisted of seven fungicides and their application rates in accordance with manufacturers' recommendations. Fungicide applications were conducted on 35 and 49 DAT, using hand sprayers. Fungicide treatments consisted of seven formulations (Table 1) and were arranged in a randomized complete block design with three replications. Each replication consisted of a plot with eight rows, $10 \mathrm{~m}$ long, a planting space of $25 \mathrm{x}$ $25 \mathrm{~cm}$, and a bare space of $1.5 \mathrm{~m}$ between plots. The experimental plots were surrounded by farmers' plantations with 30 DAT old of Filipin, which were heavily infected by leaf blast. Leaf blast severity was scored at 42,49 , and 56 days after transplanting. Percentage diseased leaf area was visually estimated on 20 randomly selected hills per plot for AUDPC estimation using formula 1 above.

Table 1. Fungicides (with manufacturers, active ingredients, and dosage rates) used in the study

\begin{tabular}{lllc}
\hline Fungicides & Manufacturer & \multicolumn{1}{c}{ Active ingredient } & Dosage rate $^{\mathrm{a}}$ \\
\hline Nustar 400 EC & Dupont Indonesia & Flusilazol & $0.6 \mathrm{ml}$ \\
Score 250 EC & PT. Syngenta Indonesia & Difenoconazole & $1.0 \mathrm{ml}$ \\
Arytop 300 SC & Dupont Indonesia & Difenokonazole+Propikonazole & $0.8 \mathrm{ml}$ \\
Delsen MX-80 WP & PT. Syngenta Indonesia & Carbendazim (6.2\%)+mancozeb (73.8\%) & $2.0 \mathrm{~g}$ \\
Ridomil 14/64 WG & PT. Johny Jaya makmur & Menefoxam (4\%)+mancozeb (64\%) & $5.0 \mathrm{~g}$ \\
Wendry 75 WP & PT. Multi Sarana Indotani & Chlorothalonyl & $1.5 \mathrm{~g}$ \\
Starmyl 25 WP & PT. Multi Sarana Indotani & Metalaxyl & $0.8 \mathrm{~g}$ \\
\hline
\end{tabular}

${ }^{\mathrm{a}}$ Dosage rate per liter of water;

${ }^{\mathrm{b}}$ Recommended for use in rice. Other fungicides tested for experimental purpose only.

Neck blast severity was scored seven days before harvest, by randomly observing 100 panicles per plot. For neck blast evaluation, while percentage neck blast was determined by counting the number of panicles showing neck blast symptoms among 100 sample plants in each plot (Formula 2).

Crop yield was assessed by randomly collecting 50 panicles per plot at harvest time. The panicles were dried under the sun for three days (about $20 \mathrm{~h}$ ) before the grains were removed from panicles. Grain weight and the number of unfilled grains per panicle were then determined. 


\subsection{Statistical Analysis}

Analysis of variance (ANOVA) was used to determine the effects of cultivar, planting date, or fungicide on LBS or NBI. For the fungicide and planting date trials, ANOVA was also performed to determine the effects of fungicide on the yield. The percent data were arcsine-transformed before being subjected to ANOVA. When significant differences were detected, means were separated using Tukey's test at 5\% probability level.

\section{Results and Discussion}

\subsection{Blast Infection on Four Rice Varieties}

Under field conditions with abundant inoculum sources and without fungicide applications, leaf blast severity, NBI, and percent of unfilled grains were significantly affected by cultivar (Table 2). Average AUDPC on Filipin was significantly higher, followed by Cigeulis, Cisantana, and IR-66. Based on leaf blast scoring, the varieties: IR-66 and Cisantana, Cigeulis, Filipin can respectively be described as moderately resistant, moderately susceptible, and completely susceptible. Varietal reactions to neck blast were similar to their reaction to leaf blast, except Cisantana reacted as moderately susceptible to neck blast. The percentages of unfilled grains were significantly lower on Cigeulis and Cisantana compared to Filipin but still significantly higher than IR-66. Thirty one percent of plant population in the Filipin plots died due to the disease, while no plants died in plots of other varieties.

Table 2. Reactions of four rice varieties: Filipin, Cigeulis, Cisantana, and IR-66 to blast, expressed as values of AUDPC, NBI, and percentage unfilled grains

\begin{tabular}{lccccc}
\hline & \multicolumn{2}{c}{ Leaf blast } & & Neck blast & \\
\cline { 2 - 3 } Rice Varieties & AUDPC (\% day) & $\begin{array}{c}\text { Average } \\
\text { score/Reaction }\end{array}$ & & $\begin{array}{c}\text { Percent incidence } \\
\text { /Reaction }\end{array}$ & $\begin{array}{c}\text { Percent of unfilled } \\
\text { grains }\end{array}$ \\
\cline { 2 - 3 } Filipin & $837.8 \mathrm{a}$ & $6.1 / \mathrm{S}$ & & $75.0 \mathrm{a} / \mathrm{S}$ & $69.5 \mathrm{a}$ \\
Cigeulis & $67.3 \mathrm{~b}$ & $4.5 / \mathrm{MS}$ & & $46.3 \mathrm{~b} / \mathrm{MS}$ & $35.4 \mathrm{~b}$ \\
Cisantana & $34.5 \mathrm{c}$ & $3.2 / \mathrm{MR}$ & & $34.0 \mathrm{bc} / \mathrm{MS}$ & $27.3 \mathrm{~b}$ \\
IR-66 & $16.7 \mathrm{c}$ & $2.9 / \mathrm{MR}$ & & $24.0 \mathrm{c} / \mathrm{MR}$ & $17.6 \mathrm{c}$ \\
\hline
\end{tabular}

Numbers in same column followed by same letters are not significantly different ( $\mathrm{P}=0.05$, Tukey's test). Percent data were arcsine-transformed before being subjected to ANOVA. Plant reactions: $\mathrm{S}=$ susceptible, $\mathrm{MS}=$ moderately susceptible, $\mathrm{MR}=$ moderately resistant, $\mathrm{R}=$ resistant.

The experimental site was a rain-fed area, about $10 \mathrm{~m}$ above sea level. The area had experienced severe blast incidence for the last two years prior to initiation of the study, but the disease had never before been reported as causing serious damage in the area. Our results indicate that the problem might stem from the introduction of a highly susceptible rice variety, Filipin, which was introduced to the area four years before the study was conducted. Since its introduction it had become popular among farmers because of its high-yielding potential, and the fact that about $50 \%$ of the area was planted with the variety at the time of the study. Before the introduction of Filipin, most farmers planted IR-66, Cigeulis, and Cisantana. The current study results show that IR-66 and Cisantana are moderately resistant and Cigeulis is moderately susceptible to blast. These cultivars have been planted for many years in the experimental area without serious damage by blast. They seemed to have partial resistance, controlled by multiple genes, against the disease, offering more stable form of resistance (Manosalva et al., 2009). However, the results also showed relatively high neck blast incidence and percent unfilled grains which might be caused by the intense pressure of inoculum coming from the Filipin plants. The IR-66 is categorized as moderately resistant against the blast disease (BBPTP, 2009) but there is no previous information available about how Cisantana, Cigeulis, and Filipin react to blast disease.

\subsection{Planting Period Effect}

Planting date treatment effects were significant for all traits measured in the experiment (Table 3). Total AUDPC values for the three observation dates showed that plants transplanted on March 22 had significantly higher 
infection rate and percent unfilled grains compared with those planted six weeks earlier (Feb 4) or six weeks later (May 16). There were no significant differences in AUDPC values and NBI between plants transplanted in Feb 4 and May 16. However, percent empty grains on plants transplanted in May was significantly lower than the other planting periods. Average weight of filled grains was the highest on the plants planted in February, followed by May, and then March. No significant differences in the yield weight between plants transplanted on February and May but they were significantly higher than those planted in March.

Table 3. Average of AUDPC, NBI, and percentage unfilled grains of Filipin planted at different planting periods

\begin{tabular}{lcccc}
\hline Planting date & $\begin{array}{c}\text { Total AUDPC } \\
(\% \text { day })\end{array}$ & $\begin{array}{c}\text { Percent of neck } \\
\text { blast }\end{array}$ & $\begin{array}{c}\text { Percent of unfilled } \\
\text { grains }\end{array}$ & Yield (mg/10 panicles) \\
\hline 15 March 2011 & $117 \mathrm{a}$ & $23 \mathrm{a}$ & $25 \mathrm{~b}$ & $1,500 \mathrm{~b}$ \\
1 May 2011 & $322 \mathrm{~b}$ & $53 \mathrm{~b}$ & $54 \mathrm{c}$ & $920 \mathrm{a}$ \\
16 Jun 2011 & $200 \mathrm{~b}$ & $16 \mathrm{a}$ & $9 \mathrm{a}$ & $1,350 \mathrm{~b}$ \\
\hline
\end{tabular}

Numbers in same column followed by same letters are not significantly different $(\mathrm{P}=0.05$, Tukey's test $)$. Percent data were arcsine-transformed before being subjected to ANOVA.

Similarly, planting period treatments affected AUDPC values for each of the three observations (Figure 1). On 30 and 37 DAT, AUDPC values on plants planted in February was significantly lower than those planted in March and May. However, on 44 DAT, disease severity on plants planted in May decreased to the levels lower than those of the other treatments, and were significantly lower than the levels on plants planted in March.

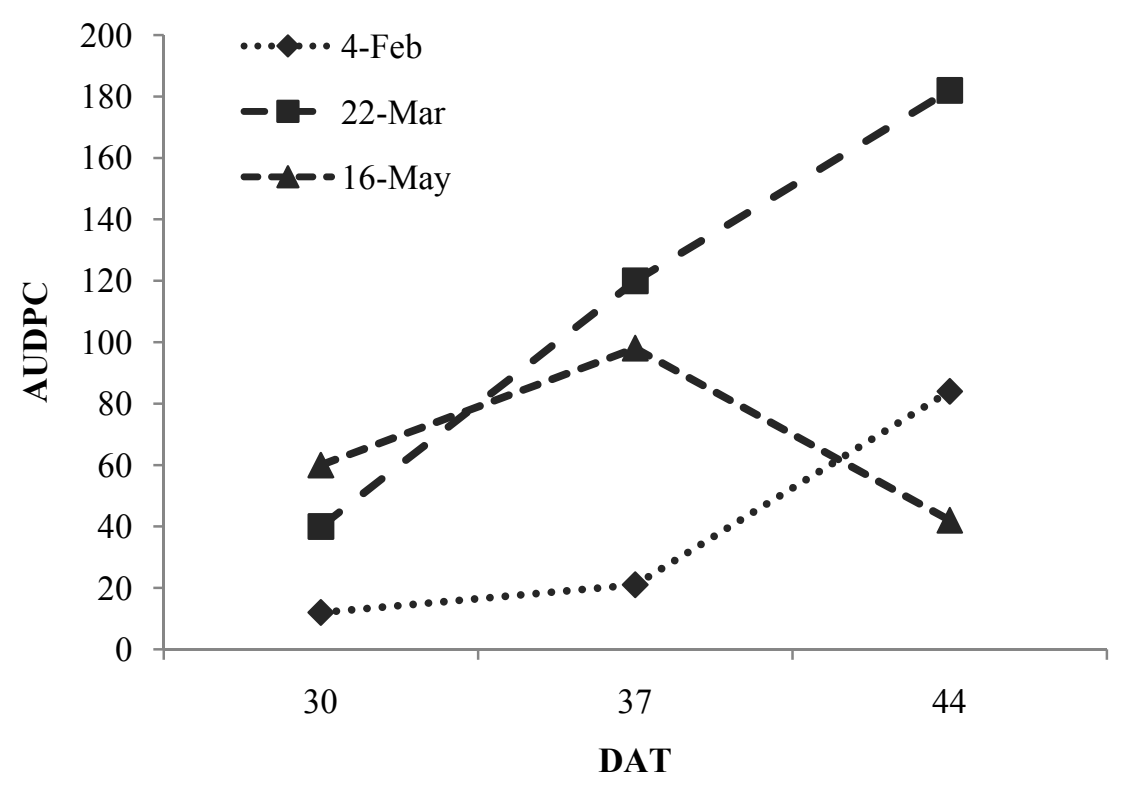

Figure 1. Leaf blast progress on rice var. Filipin transplanted in February, March, and May, 2011, observed at 30, 37, and 44 DAT. DAT=days after transplanting

The low values of AUDPC, NBI, and percent unfilled grains on plants transplanted early in the season were probably caused by the low inoculum sources and the availability of excessive water that flooded the plantation. In tropical areas, flooding the soil as often as possible can be effective in suppressing blast incidence (Lee et al., 2003; IRRI, 2010). 
The results also showed that the values of NBI and percent unfilled grains on the plants transplanted late in the season were significantly lower than those transplanted in March. This result contradicts with previous findings that when epidemics start earlier, in late sown plantings, plant growth and developments will be severely affected, resulting in death of many plants (Filippi \& Prabu, 1997). The contradictory results were probably caused by low rainfall and humidity at the end of the season at the experimental area (Figure 2). High humidity and frequent rainfall create environmental conditions conducive for rice blast infection (Lee et al., 2005).

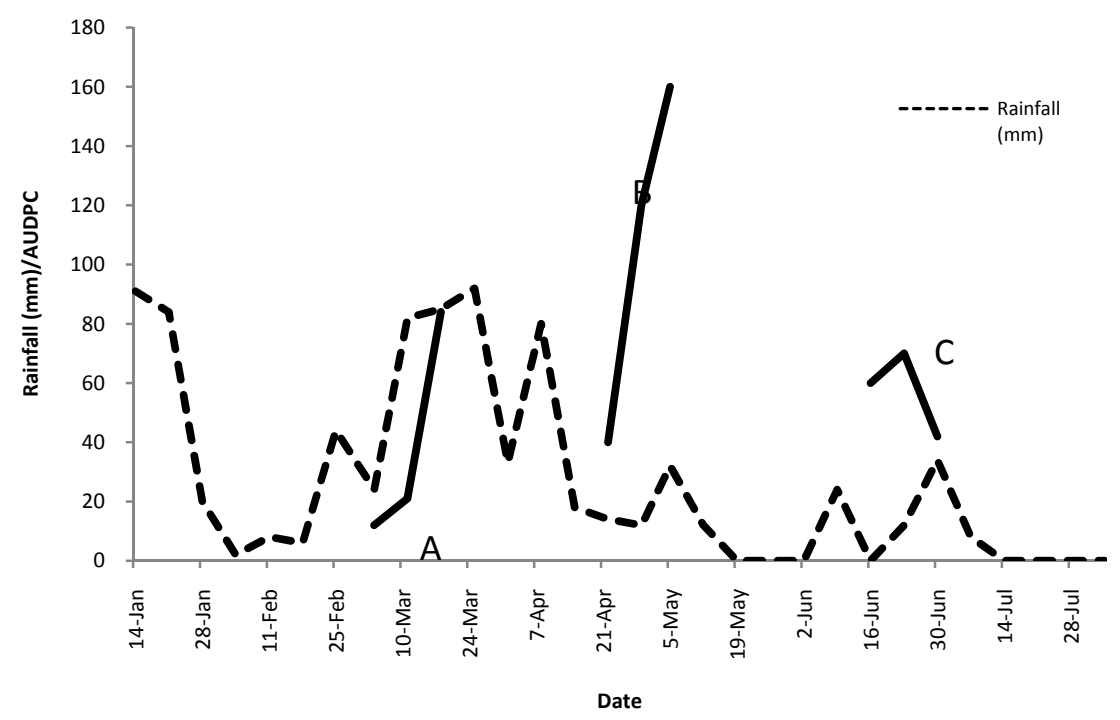

Figure 2. Weekly rainfall values in the experimental area, from March to August 2011 (Source: Meteorology and Climatology Station, Maros, South Sulawesi Indonesia, 2011). A=transplanted on February 4, B=transplanted on March 22, C=transplanted on May 16. Blast AUDPCs were evaluated at 30, 37, and 44 DAT

\subsection{Fungicide Effect}

Effects of different fungicide formulations on LBS are presented in Tables 3 and 4. On all observation dates, flusilazol, difenoconazole, difenoconazole + propiconazole, and carbendazim $6.2 \%+$ mancozeb $64 \%$ consistently showed lower AUDPC values compared to the other treatments. These were followed by menefoxam $4 \%+$ mancozeb $64 \%$, chlorothalonyl, and metalaxyl whose AUDPC values were not significantly different from each other but significantly lower than the untreated control.

Table 4. Average AUDPC values of leaf blast for fungicide treatments on 42, 49, and 56 DAT

\begin{tabular}{lcrrrr}
\hline \multirow{2}{*}{ Fungicide } & \multirow{2}{*}{ Dosage (ml/liter of water) } & \multicolumn{4}{c}{ AUDPC values (\% day) of LB } \\
\cline { 3 - 6 } & & 42 DAT & 49 DAT & 56 DAT & TOTAL \\
\hline Flusilazol & 0.6 & $57.3 \mathrm{c}$ & $16.3 \mathrm{c}$ & $1.0 \mathrm{c}$ & $74.3 \mathrm{c}$ \\
Difenoconazole & 1.0 & $65.1 \mathrm{c}$ & $12.3 \mathrm{c}$ & $1.2 \mathrm{c}$ & $88.6 \mathrm{c}$ \\
Difenokonazole+propikonazole & 0.8 & $64.2 \mathrm{c}$ & $18.9 \mathrm{c}$ & $4.1 \mathrm{c}$ & $87.2 \mathrm{c}$ \\
Carbendazim+mancozeb & 2.0 & $64.4 \mathrm{c}$ & $38.3 \mathrm{c}$ & $3.9 \mathrm{c}$ & $106.6 \mathrm{c}$ \\
Menefoxam+mancozeb & 5.0 & $136.6 \mathrm{~b}$ & $74.9 \mathrm{~b}$ & $45.2 \mathrm{~b}$ & $256.7 \mathrm{~b}$ \\
Chlorothalonyl & 1.5 & $125.1 \mathrm{~b}$ & $97.9 \mathrm{~b}$ & $54.6 \mathrm{~b}$ & $277.6 \mathrm{~b}$ \\
Metalaxyl & 0.8 & $152.4 \mathrm{ab}$ & $74.5 \mathrm{~b}$ & $67.5 \mathrm{~b}$ & $294.4 \mathrm{~b}$ \\
Control & - & $172.1 \mathrm{a}$ & $277.2 \mathrm{a}$ & $279.2 \mathrm{a}$ & $728.8 \mathrm{a}$ \\
\hline
\end{tabular}

Numbers in same column followed by same letters are not significantly different ( $\mathrm{P}=0.05$, Tukey's test). 
For the NBI, percentage unfilled grains, and weight of filled grains were significantly affected by the fungicide formulations (Table 5). Flusilazol, difenoconazole, and difenoconazole+propiconazole were effective in suppressing NBI and percentage unfilled grains. In this experiment, carbendazim $6.2 \%+$ mancozeb $64 \%$ was less effective in controlling neck blast than leaf blast. All fungicide treatments had higher yield than the control treatment. The highest yields were obtained from plants treated with flusilazol, difenoconazole, and difenoconazole+propiconazole; followed by carbendazim $6.2 \%+$ mancozeb $64 \%$, menefoxam $4 \%+$ mancozeb $64 \%$, metalaxyl, and chlorothalonyl.

Table 5. Neck blast incidence (NBI), percentage unfilled grains, and grain weight per 10 panicles for all fungicide treatments

\begin{tabular}{lcccc}
\hline Fungicide & $\begin{array}{c}\text { Rate (ml/liter of } \\
\text { water) }\end{array}$ & NBI & $\begin{array}{c}\text { Percent of unfilled } \\
\text { grains/panicle }\end{array}$ & $\begin{array}{c}\text { Grain weight/10 } \\
\text { panicles (mg) }\end{array}$ \\
\hline Flusilazol & 0.6 & $9.3 \mathrm{c}$ & $5.0 \mathrm{c}$ & $1,450 \mathrm{a}$ \\
Difenoconazole & 1.0 & $13.3 \mathrm{c}$ & $6.2 \mathrm{c}$ & $1,325 \mathrm{a}$ \\
Difenokonazole+propikonazole & 0.8 & $15.9 \mathrm{c}$ & $4.2 \mathrm{c}$ & $1,510 \mathrm{a}$ \\
Carbendazim+mancozeb & 2.0 & $44.8 \mathrm{~b}$ & $46.7 \mathrm{~b}$ & $843 \mathrm{~b}$ \\
Menefoxam+mancozeb & 5.0 & $57.1 \mathrm{~b}$ & $51.0 \mathrm{~b}$ & $650 \mathrm{c}$ \\
Chlorothalonyl & 1.5 & $44.4 \mathrm{~b}$ & $48.6 \mathrm{~b}$ & $575 \mathrm{c}$ \\
Metalaxyl & 0.8 & $40.0 \mathrm{~b}$ & $50.0 \mathrm{~b}$ & $725 \mathrm{c}$ \\
Control & - & $94.0 \mathrm{a}$ & $82.0 \mathrm{a}$ & $320 \mathrm{~d}$ \\
\hline
\end{tabular}

Numbers in same column followed by same letters are not significantly different ( $\mathrm{P}=0.05$, Tukey's test). Percent data were arcsine-transformed before being subjected to ANOVA.

In this study flusilazol, difenoconazole, difenoconazole+propiconazole, and carbendazim $6.2 \%+$ mancozeb $64 \%$, which are recommended for use in rice (as stated on the product labels), effectively suppressed leaf blast severity. However, carbendazim $6.2 \%+$ mancozeb $64 \%$ was less effective in controlling neck blast incidence and showed lower yield compared to flusilazol, difenoconazole, and difenoconazole+propiconazole. The yields of plants treated with flusilazol, difenoconazole, and difenoconazole+propiconazole were 4.5, 4.1, and 4.7 times higher than yields of the untreated plants, respectively. Fungicides with the active ingredients of difenoconazole and difenoconazole+propiconazole were effective in suppressing the blast disease (Ghazanfar et al., 2009).

\section{Conclusion}

These results demonstrate that IR-66 was moderately resistant to leaf and neck blasts, with Cisantana being moderately resistant to leaf blast but moderately susceptible to neck blast. Cigeulis was moderately susceptible to leaf and neck blasts, while Filipin variety was highly susceptible to blast, and without fungicide application, up to $31 \%$ of the plants died due to the disease. Planting early in the season when inoculum source was low and planting late in the season when humidity was low helped plants escape serious damages due to blast infection. Planting in the middle of the season predisposed plants to severe infection because of the availability of abundant inoculum sources and high humidity levels in the experimental area. It can be concluded that when planting circumstances warrant fungicide use, flusilazol, difenoconazole, difenoconazole+propiconazole, and carbendazim $6.2 \%+$ mancozeb $64 \%$ should be used alternately to suppress the disease and to prevent or at least slow down the pathogen from developing resistance against those fungicides.

\section{Acknowledgements}

The authors acknowledge M. Said Baco of the Department of Plant Pests and Diseases Hasanuddin University, for the technical assistance provided during the course of the study.

\section{References}

Balai Besar Penelitian Tanaman Padi. (BBPT). (2009). Deskripsi Varietas Padi. Badan Penelitian dan Pengembangan Pertanian Departemen Pertanian. 
Bonman, J. M., Estrada, B. A., Kim, C. K., Ra, D. S., \& Lee. E. J. (1991). Assessment of blast disease and yield loss in susceptible and partially resistant rice cultivars in two irrigated lowland environments. Plant Disease, 75, 462-466. http://dx.doi.org/10.1094/PD-75-0462

Chaudary, B. (2001). Rice blast: pathogenic variability and host resistance. MSc. Thesis. Tribhuvan University, IAAS, Rampur, Chitwan, Nepal.

Filippi, M. C., \& Prabu, A. S. (1997). Integrated effects of host plant resistance and fungicidal seed treatment on panicle blast progress and grain yield. Fitopatologia Brasileiram, Brasil, 2, 164 -170.

Ghazanfar, M. U., Wakil, W., Sahi, S. T., \& Yasin, S. I. (2009). Influence of various fungicides on the management of rice blast disease. Mycopath, 7, 29-34.

Greer, C. A., \& Webster, R. K. (2001). Occurrence, Distribution, Epidemiology, Cultivar Reaction and Management of Rice Blast Disease in California. Plant Disease, 85, 1196-1202. http://dx.doi.org/10.1094/PDIS.2001.85.10.1096

Groth, D. E. (2006). Azoxystrobin rate and timing effects on rice head blast incidence and rice grain and milling yield. Plant Disease, 90, 1055-1058. http://dx.doi.org/10.1094/PD-90-1055

Hasanuddin, A. (2004). Pengendalian hama dan penyakit padi: Upaya tiada henti. Inovasi Pertanian Tanaman Pangan. Pusdlitbangtan Bogor.

International Rice Research Institute. (2010). Rice Blast. Rice fact sheets. Rice Science for Better World.

International Rice Research Institute. (2011). Rice SES. Retrived November 20, 2011 from http://www.knowledgebank.irri.org/extension/index.php/crop-damage-diseases/panicle-blast-pb

Lee, F. N., Cartwright, R. D., Wilson, C. E., \& Moldenhauer, K. A. K. (2005). Historical use of field resistance to control rice blast disease in Arkansas. Pest Management Diseases. AAES Research Series, 540.

Lee, F. N., Singh, M. P., Counce, P. A., \& Gibbons, J. H. (2003). The Mediation Mechanism for flood-induced rice blast field resistance. Pest Management Diseases. AAES Research Series, 517.

Manosalva, P. M., Davidson, R. M., Liu, B., Zhu, X. Y., Hulbert, S. H., Leung, H., \& Leach, J. E. (2009). A germin-like protein gene family functions as a complex quantitative trait locus conferring broad-spectrum disease resistance in rice. Plant Physiol., 149, 286-296. http://dx.doi.org/10.1104/pp.108.128348

Prabhu, A. S, Filippi, M. C, \& Zimmermann, F. J. P. (2003). Cultivar response to fungicide application in relation to rice blast control, productivity and sustainability. Pesq. Agropec. Bras., Brasília, 38, 11-17.

Puri, K. D., Shrestha, S. M., ChHetery, G. B. K., \& Joshi, K. D. (2009). Leaf and neck blast resistance reaction in tropical rice lines under greenhouse condition. Euphytica, 165, 523-532. http://dx.doi.org/10.1007/s10681-008-9771-9

Shaner, G., \& Finney, R. E. (1977). The effect of nitrogen fertilization on the expression of slow-mildewing resistance in Knox wheat. Phytopathology, 67, 1051-1056. http://dx.doi.org/10.1094/Phyto-67-1051

Singh, M. P., Lee, F. N., Counce, P. A., \& Gibbons, J. H. (2004). Mediation of partial resistance to rice blast through anaerobic induction of ethylene. Phytopathology, 94, 819-825. http://dx.doi.org/10.1094/PHYTO.2004.94.8.819

Tangdiabang, J., \& Pakki, S. (2006). Penyakit blast (Pyricularia grisea) dan strategi pengendaliannya pada tanaman padi. Pusat Penelitian Tanaman Pangan. Departemen Pertanian, 7, 241-245.

Wibowo, B. S. (2011). Sebaran dan perkembangan OPT padi. Prosiding Seminar Nasional Penyakit Tungro. Makassar, Indonesia. 